\title{
Immobilisation of Cells in Biocompatible Films to Cell Therapy
}

\author{
Eva. M. Martín Del Valle*, Edgar P. Herrero, Dina A. O. Martins and Miguel. A. Galán
}

Department of Chemical Engineering, University of Salamanca, P/Los Caidos S/N, 37008, Salamanca, Spain

\begin{abstract}
In this work a new system for immobilisation of cells was developed based on biocompatible alginate bariumfilms. Films are prepared to allow better control over film thickness and produce better film uniformity, avoiding roughness over film surface that can produce fibrosis and rejection after transplantation.

In this study monocyte, mononuclear and fibroblast cell lines were immobilised in micrometric $(\approx 300$ microns of thickness) barium alginate films. The system was able to maintain the cell viability of all the three types of cells for at least two weeks after immobilisation, but cell proliferation was only verified for the monocyte and fibroblast cell lines.
\end{abstract}

Key Words: Immobilisation, alginate barium membranes, cell therapy, cell viability.

\section{INTRODUCTION}

Cell therapy is one of the most exciting fields in translational medicine. It stands at the intersection of a variety of rapidly developing scientific disciplines: stem cell biology, immunology, tissue engineering, molecular biology, biomaterials, transplantation biology, regenerative medicine, and clinical research. Cell-based therapy may develop into a new therapeutic platform to treat a vast array of clinical disorders. The aim of cell therapy is to replace, repair or enhance the function of damaged tissues or organs.

The pneumonectomy (pulmonary resection) is a surgical procedure to remove a lung and it is used to excise tumourous tissue arising from lung cancer, and rarely for treatment of tuberculosis. Despite careful selection in the pre-operative period, high rates of early mortality $(9.1 \%)$ and morbidity remain after phneumonectomy in our country [1]. One of the most serious complications after the surgical procedure is the post pneumonectomy bronchopleural fistula (BPF). BPF is defined as a communication between the bronchial tree and the pleural space through the bronchial stump that usually results after pulmonary resection [2].

One successful approach to the treatment of this surgical complication is the tissue repairing by polymeric systems containing different cells lines, such us monocytes, mononuclear rand fibroblasts [3].

Monocytes are produced by the bone marrow from haematopoietic stem cell precursors and produce growth factors, such as VEGF (Vascular Endothelial Growth Factor), bFGF (Basic Fibroblast Growth Factor) and TNF- $\alpha$ (Tumour Necrosis Factor- $\alpha$ ) with molecular weights of $42 \mathrm{KDa}, 16 \mathrm{KDa}$, $27 \mathrm{KDa}$, respectively, that are very important to the angiogenesis [4-6]. The ideal method to obtain monocytes is the isolation by adherence from peripheral blood mononuclear

*Address correspondence to this author at the Department of Chemical Engineering, University of Salamanca, P/Los Caídos S/N, 37008, Salamanca, Spain; E-mail: emvalle@usal.es cells [7]. Then, in this work mononuclear cells were also used to be able to work with a bigger number of cells.

A fibroblast is a type of cell that synthesises and maintains the extracellular matrix of many animal tissues. Fibroblasts provide a structural framework (stroma) for many tissues, and play a critical role in wound healing. They are the most common cells of connective tissue in animals.

Coverage of the bronchial stump with autologous tissue of fibroblast [8,9], vascular endothelial growth factor (VEGF) [10] and basic fibroblast growth factor (bFGF) [10] reduces the risk of postoperative death due to BPF after pneumonectomy.

Several factors complicate the development of cellular therapies. Of primary importance is protection of the implanted cells from the host's immune system to prevent the freshly grafted cells from attack by native killer cells. A highly undesirable solution to immuno-rejection is the regular administration of a cocktail of immunosuppressants that can result in serious side effects.

In this work, we demonstrate a method for non-autologous cellular transplantation that mitigates immune rejection without immunosuppressants. To do that, cells were immobilised in support with semi-permeable and biocompatible membranes that provide mechanical protection to block entry of immune mediators, allowing outward diffusion of the growth factors produced by the cells to allow treatment of the disease. In addition, this membrane permits the entry of nutrients and oxygen, and the exit of waste [11$15]$.

During the last years, the major efforts have been dedicated to develop spherical microcapsules to cell therapy [16], but recently other type of cell immobilisation polymeric devices is taking importance, the immobilisation within polymeric films [17]. Cell immobilisation within films presents some advantages in comparison with microcapsules in some kinds of treatments; they are easy to retrieval in case of 
complications [18] and are useful in tissue repairing [19] and wounds treatment.

In addition, their mechanical strength must be adequate to the applications required. Films will be fixed using sutures by surgery, and in cases as myocardial repair will be exposed to considerable tautness that barium alginate compounds should resist. Mechanical resistance tests have been made to ensure that barium alginate films present an appropriate elastic modulus.

Several studies on the pore size of the microcapsules has been completed. Changes in pore size determine the molecular weight cut-off of factors that can be released. A. Del Pozo et al. [20] considered an innovating technique that consists of the microencapsulation of a coloured substance that is available in several molecular weights $(10-70 \mathrm{KDa})$, Rhodamine B isothiocyanate-Dextran. This allows the monitoring of its release by spectrophotometer measure, and as it is available in diverse molecular weights it allows simulate different kinds of molecules, that are of interest. Like microcapsules films must be controlled so factors can be released from cells.

There are two habitual techniques proposed to produce films using alginates: first process consists in dehydrate an alginate layer before crosslinking [21], this technique is not adequate because desiccation process will damage cells; second process consists in extend a thin alginate layer over a Petri dish and then crosslinking [22], this process could be applied to our case, but currently it is difficult to control film thickness and uniformity.

In this paper a relevant and new cellular immobilisation system based on biocompatible alginate barium-films is described. This new way to prepare films allows a better control over film thickness and makes better film uniformity, avoiding roughness over film surface that can produce fibrosis and rejection after transplantation.

Based on this new technology of producing biocompatible films with a high mechanical stability and a specific thickness, the main aim of this work is to achieve the cell immobilisation of different cell lines within the immobilisation system. Cell viability was investigated using MTT (3-[4,5-dimethylthiazol-2-yl]-2,5-diphenyl tetrazolium bromide) assay.

\section{MATERIALS AND METHODS}

\section{Materials}

Sodium alginate from macrocystis pyrifera (medium viscosity) was purchased from Sigma Chemicals, barium chloride dihydrate, reagent grade was purchased from Scharlau, cell growth determination kit [3-[4,5-dimethylthiazol-2-yl]2,5-diphenyl tetrazolium bromide (MTT solution), and $0.1 \mathrm{~N}$ $\mathrm{HCl}$ in anhydrous isopropanol (MTT solvent)] was purchased from Sigma Chemicals, complete growth medium consisting of Dulbecco's modified Eagles medium (DMEM) was purchased from GIBCO and supplemented with $10 \%$ foetal calf serum from CAMBREX, $1 \%$ penicillin/streptomycin from GIBCO, and sterilized by filtration through $0.45-\mu \mathrm{m}$ membranes obtained from Millipore.

\section{Cell Lines}

Different cell lines were used in this study, monocytes and mononuclear cells from peripheral blood were obtained from the Haematology Service of the University Hospital of Salamanca, and fibroblast from the ocular surface of pork obtained from the Tissue Service of the San Francisco Clinic (León).

\section{Production of the Films}

$15 \times 10^{6}$ of monocytes were supplied in $2 \mathrm{~mL}$ of medium of culture and diluted with a solution of alginate-medium until $15 \mathrm{~mL}$ of $2 \% \mathrm{wt}$. alginate-cell suspension of $1 \times 10^{6}$ cells / $\mathrm{mL}$.

$136 \times 10^{6}$ of mononuclear cells were supplied in $2 \mathrm{~mL}$ of medium of culture and diluted with a solution of alginatemedium until $7 \mathrm{~mL}$ of $4 \% \mathrm{wt}$. alginate-cell suspension of $19.5 \times 10^{6}$ cells $/ \mathrm{mL}$.

$1 \times 10^{5}$ of fibroblast were supplied in $2 \mathrm{~mL}$ of medium of culture and diluted with a solution of alginate-medium until $10 \mathrm{~mL}$ of $4 \% \mathrm{wt}$. alginate-cell suspension of $1 \times 10^{4}$ cells / $\mathrm{mL}$.

The production of the films was optimised, to control and reduce the thickness (300 microns) maintaining the mechanical strength. The device to generate the biocompatible films (Fig. 1) was composed of two porous plates, fixated in a metallic support, in contact with a gripper. In each part of the device was placed a filter drenched with a $3 \%$ wt. barium chloride. On the plate that was set in the support, was spilled $0.7 \mathrm{~mL}$ of a $4 \% \mathrm{wt}$. alginate solution with cells, in the centre of the filter. The other plate was then vertically placed over the first one, and the device was fixed with the gripper. Through the entrance on the top of the device was introduced $4 \mathrm{~mL}$ of barium chloride solution so that it could cross the porous plate and contacting with the alginate thus enabling the formation of the gel, which constitutes the membrane.

The immobilisation of monocytes/mononuclear cells and fibroblasts differ in terms of permanence in the device and in a Petri dish with a $15 \mathrm{~mL}$ barium chloride solution. Films with monocytes/mononuclear cells were left for ten minutes in the device and another ten minutes in barium chloride solution in the Petri dish. Fibroblast films were left for two minutes in the device and another five minutes in the Petri dish.

There were prepared four films per cell line, which were maintained in Petri dish with $20 \mathrm{~mL}$ of complete growth medium DMEM supplemented with $10 \%$ foetal calf serum, 1 $\%$ penicillin/streptomycin. The Petri dishes were stored for culturing at $37^{\circ} \mathrm{C}$ with $5 \%$ supply of $\mathrm{CO}_{2}$ (Forma Direct Heat $\mathrm{CO}_{2}$ Incubator, Thermo Electron Corporation, Hucoa-Erlöss, and Model 311). The medium was changed each 3 days.

All barium chloride, sodium citrate solutions, were autoclaved using a steam steriliser (P-Selecta, Autester-E) at 121 ${ }^{\circ} \mathrm{C}$ for $30 \mathrm{~min}$. The alginate powder was sterilised by exposure to UV radiation during 24 hours.

All the equipment used, including all the glassware were autoclaved at $121^{\circ} \mathrm{C}$ for $30 \mathrm{~min}$. The whole process was per- 


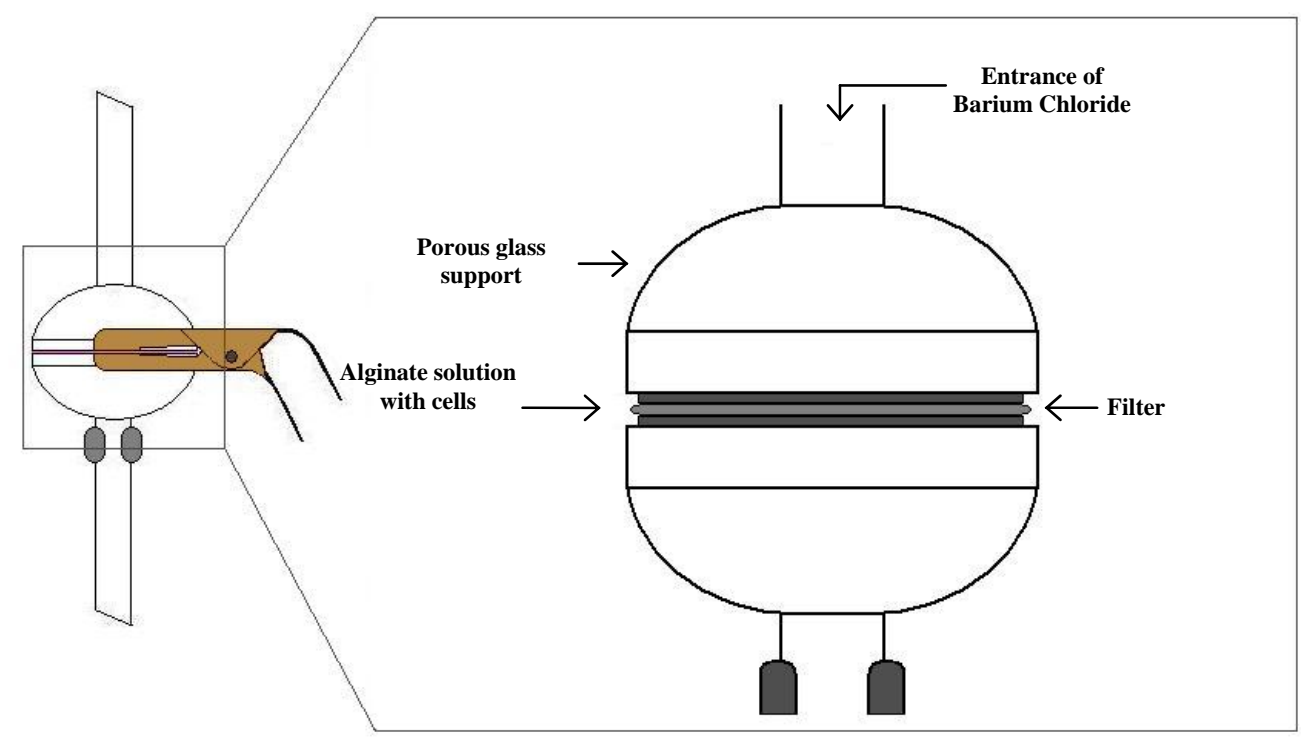

Fig. (1). Device used to prepared films with cells.

formed under sterile conditions in a class II laminar flow hood (Nuaire, Model NO-NU-425-40DE).

\section{Method of Testing Viability of Encapsulated Cells}

Encapsulated cell viability was assessed using the MTT (3-[4,5-dimethylthiazol-2-yl]-2,5-diphenyl tetrazolium bromide) assay, first described by Mosmann in 1983 [23]. Previously established procedures, as described by Uludag, were used with some modifications [24]. The reduction of tetrazolium salts is widely accepted as a reliable way to examine the cell viability in microcapsules. This viability test is based on the ability of a mitochondrial dehydrogenase enzyme from viable cells to cleave the tetrazolium rings of the pale yellow MTT and form dark blue formazan crystals, which are largely impermeable to cell membranes, thus, resulting in its accumulation within healthy cells. Solubilisation of the cells by the addition of a detergent results in the liberation of the crystals, which are solubilised. The number of surviving cells is directly proportional to the level of the formazan product created. The colour can then be quantified using a simple colorimetric assay. The results can be quantified by spectrophotometric means.

The viability tests were carried out using $100 \mu \mathrm{l}$ of culture medium with testing films per well of a 96-well microplate. Aseptically $20 \mu \mathrm{l}$ of MTT solution (Sigma-Aldrich, USA, $5 \mathrm{mg} / \mathrm{ml}$ in RPMI-1640) were added to each well and incubated at $37{ }^{\circ} \mathrm{C}$ for $3.5 \mathrm{~h}$. After the incubation period, cultures were removed from incubator and the resulting MTT formazan crystals were dissolved adding the MTT solvent $(0.1 \mathrm{~N} \mathrm{HCl}$ in anhydrous isopropanol) directly to the culture in an amount equal to the original culture volume $(100 \mu 1)$. Wells were read within 1 hour after adding MTT solvent. Pipetting up and down (trituration) is required to completely dissolve the MTT formazan crystals. Absorbance of each well was then measured in a spectrophotometer using a wavelength of $570 \mathrm{~nm}$, with reference wavelength set at $690 \mathrm{~nm}$. Blanks consisting of complete culture medium without cells were also analysed.

\section{RESULTS AND DISCUSSION}

\section{Preliminary Characterization}

The polymeric films were characterized previously and the best properties were chosen having good mechanical strength and the optimal pore size [20]. The size of the pores of the slab should be in range between 16-42 KDa to allow the release of the growth factors that the cells secrete. When the concentration of sodium alginate increases, the rhodamine release also increases, because the pore size is bigger [20]. In addition, a high mechanical resistance is required to allow the suture of the film in tissues, and it is achieved with high concentration of alginate and barium chloride; alginate concentration ( 2 and $4 \% \mathrm{wt}$.), and a barium concentration of $3.0 \% \mathrm{wt}$.

\section{Cell Calibration}

MTT assay gives absorbance values, but these values have to be associated to a quantity of living cells. A calibration was made to relate absorbance values and living cells number. Known numbers of cells were disposed in a multiwell plate and MTT assay was performed. A calibration curve was obtained; this curve represents number of known living cells vs. absorbance.

\section{a) Monocytes}

Initial cell suspension of monocytes had a cell concentration of $1.18 \times 10^{6}$ cells in $1235 \mu \mathrm{L}$. Different volumes (Table 1) were taken from the initial suspension of cells in culture medium, to obtain different known cell number, and were disposed in a multiwell plate and all the volumes were filled with fresh medium of culture until to $200 \mu \mathrm{L}$ to perform the MTT assay. Fig. (2) show the calibration curves to the monocytes cell line.

\section{b) Mononuclear Cells}

Initial cell suspension of mononuclear cells had a cell concentration of $6.5 \times 10^{6}$ cells $/ \mu \mathrm{L}$. Different volumes (Table 2) were taken from the initial suspension of cells in culture 
Table 1. Quantity of Monocyte for Calibration

\begin{tabular}{|c|c|c|c|c|c|c|c|c|c|c|c|}
\hline $\mathbf{V}, \boldsymbol{\mu L}$ & 200 & 160 & 140 & 120 & 100 & 80 & 60 & 40 & 20 & 10 & 5 \\
\hline $\mathbf{C e l l s} / \mathbf{1 0}^{\mathbf{3}}$ & 191 & 153 & 134 & 115 & 96 & 76 & 57 & 38 & 19 & 9,5 & 4.8 \\
\hline
\end{tabular}

Table 2. Quantity of Mononuclear Cells for Calibration

\begin{tabular}{|c|c|c|c|c|c|c|c|c|c|c|c|c|c|c|}
\hline $\mathbf{V}, \boldsymbol{\mu L}$ & 150 & 130 & 120 & 100 & 90 & 80 & 70 & 60 & 50 & 40 & 30 & 20 & 10 & 5 \\
\hline Cells $/ \mathbf{1 0}^{\mathbf{6}}$ & 6.5 & 5.6 & 5.2 & 4.3 & 3.9 & 3.5 & 3.0 & 2.6 & 2.2 & 1.7 & 1.3 & 0.9 & 0.4 & 0.2 \\
\hline
\end{tabular}

medium, to obtain different known cell number, and were disposed in a multiwell plate and all the volumes were filled with fresh medium of culture until to $150 \mu \mathrm{L}$ to perform the MTT assay. Fig. (3) show the calibration curves to the mononuclear cell line.

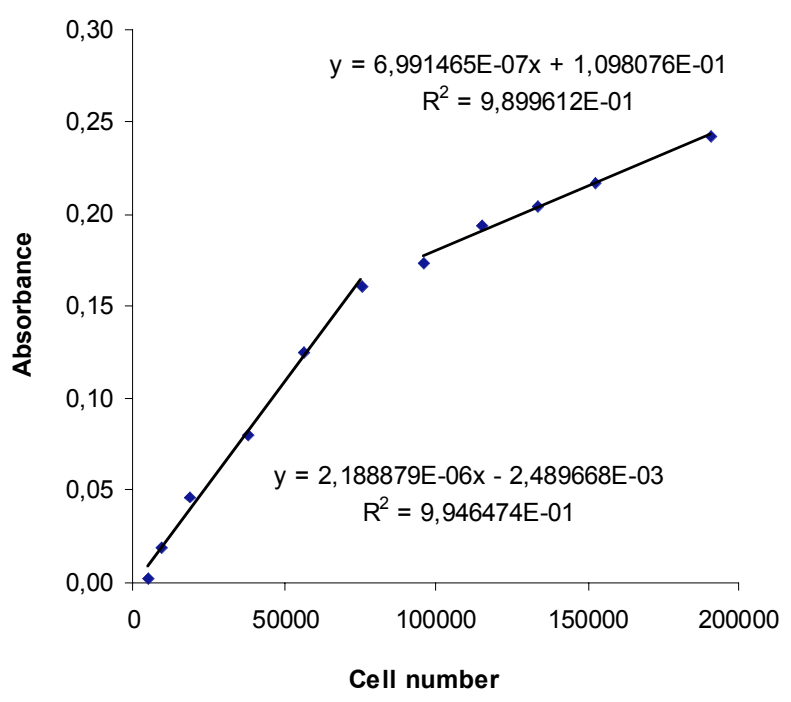

Fig. (2). Cell calibration to the monocytes cell line.

\section{c) Fibroblasts}

Initial cell suspension of fibroblast had a cell concentration of $1.0 \times 10^{6}$ cells / $\mu$ L. Different volumes (Table 3) were taken from the initial suspension of cells in culture medium, to obtain different known cell number, and were disposed in a multiwell plate and all the volumes were filled with fresh medium of culture until to $150 \mu \mathrm{L}$ to perform the MTT assay. Fig. (4) show the calibration curves to the fibroblast cell line.

\section{Viability of Encapsulated Cells}

The main aim in the present work is to achieve the viability of cells immobilised in the alternative supports of films produced by gelation processes. For the review of literature immobilisation of these cell lines was not achieved before.

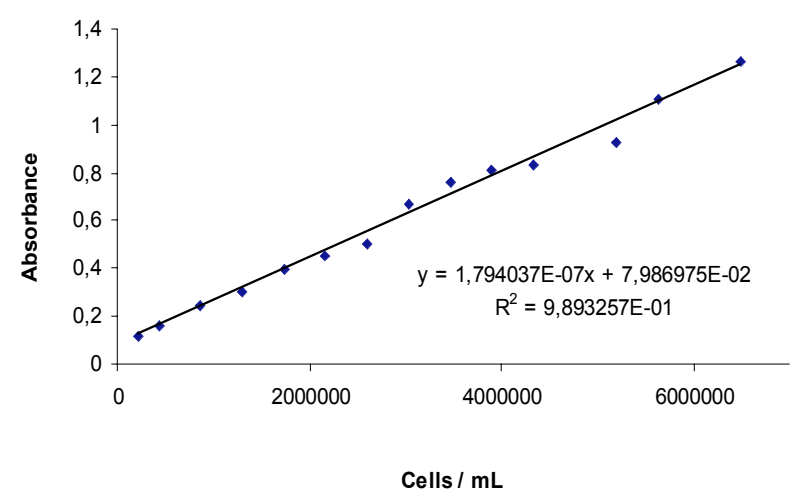

Fig. (3). Cell calibration to the mononuclear cell line.

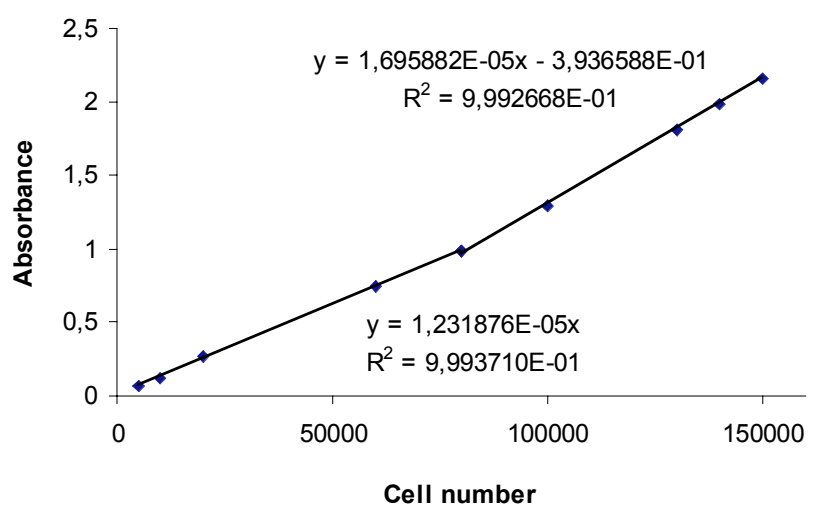

Fig. (4). Cell calibration to the fibroblast cell line.

To test whether the cells could survive within the micrometric alginate-barium films, the cell viability was monitored using an MTT (3-[4,5-dimethylthiazol-2-yl]-2,5-diphenyl tetrazolium bromide) assay.

\section{Table 3. Quantity of Fibroblast for Calibration}

\begin{tabular}{|c|c|c|c|c|c|c|c|c|c|}
\hline $\mathbf{V}, \boldsymbol{\mu L}$ & 150 & 140 & 130 & 100 & 80 & 60 & 20 & 10 & 5 \\
\hline Cells $/ \mathbf{1 0}^{\mathbf{5}}$ & 1.5 & 1.4 & 1.3 & 1.0 & 0.8 & 0.6 & 0.2 & 0.1 & 0.05 \\
\hline
\end{tabular}




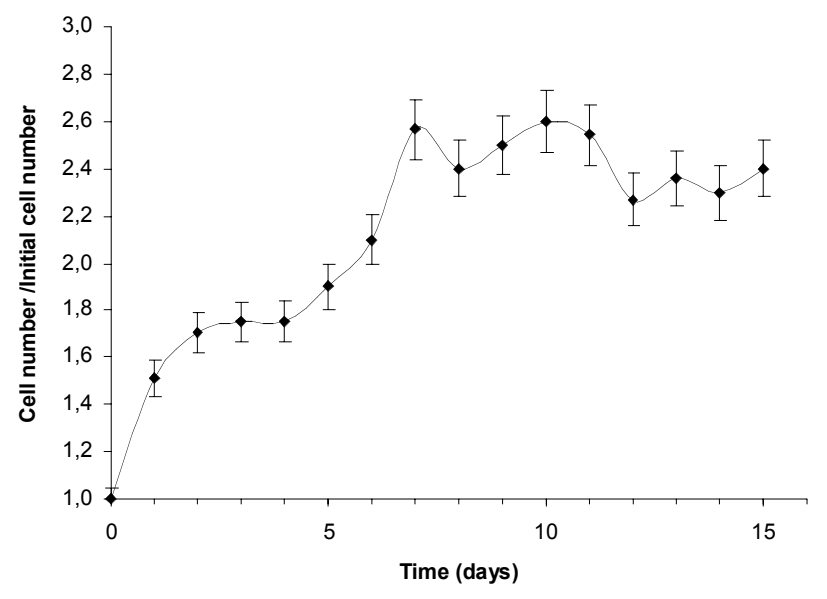

Fig. (5). Cell viability for monocytes.

According to Fig. (5), in the first day after immobilisation of monocytes cell line, cell population increases $50 \%$ with respect to the initial cells quantity. Cells continue proliferating and reach repeatedly local maximums. Generally analysing the variation of cell viability in the barium alginate membranes produced, related to the initial number, it's possible to see a general trend of cell proliferation.

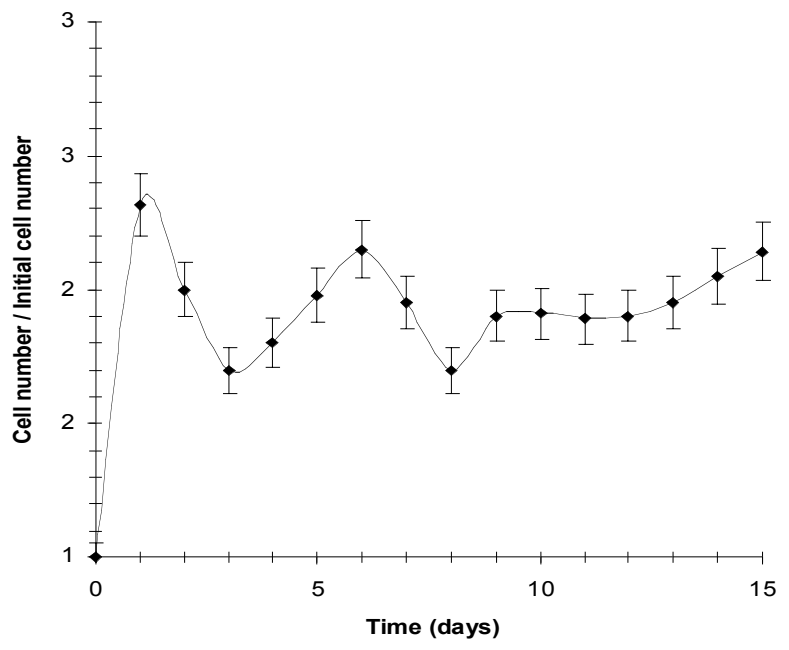

Fig. (6). Cell viability for mononuclear cells.

In the case of the mononuclear cell line (Fig. 6), analysing the data in the fifteen days of the analysis it can be referred that the used system Ba-ALG allows cell viability but doesn't permit cell proliferation. There isn't any trend of cell growth, but the number of viable cells has remained at or above the initial value.

With fibroblast cell line (Fig. 7), generally analysing the variation of cell viability in the barium alginate membranes produced, related to the initial number, it's possible to see that cell proliferation occurs since it is detected a quantity of cells always higher than the initial amount. On the other hand, there are two reading points discordant of the trend of cell proliferation that can be explained by not significant sample, which contained a smaller quantity of cells then expected.

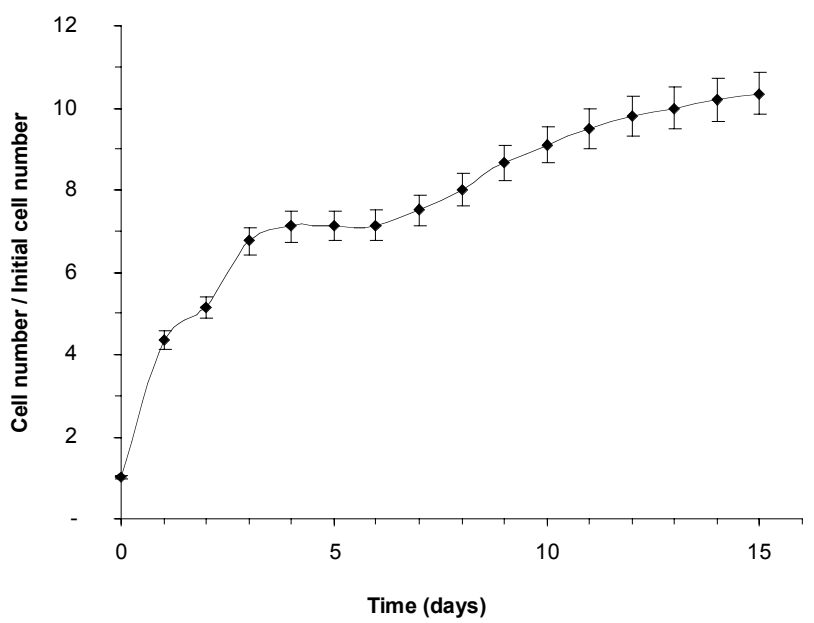

Fig. (7). Cell viability for fibroblast.

The data variation could be justified by the fact that not all films contain the same number of cells, and ELISA measure depends on the sample chosen; however, cell viability in Ba-ALG membranes is assure in all cases for at least fifteen days; all measures are over the initial cell quantity. A certain cell proliferation inside the film is proved in two cell lines.

\section{CONCLUSIONS}

In this study, was successfully achieved, the immobilisation of monocyte, mononuclear and fibroblast cell lines, in micrometric $(\approx 300$ microns of thickness) barium alginate membranes with supplemented growth medium, based on gelification processes.

The system used proved to be a good alternative to encapsulate the types cells mentioned, revealing itself an suitable system to maintain cell viability of all the three types of cells and enable cell proliferation of monocyte and fibroblast cell lines for at least fifteen days.

\section{ACKNOWLEDGMENTS}

The authors gratefully acknowledge Haematology Service of the University Hospital of Salamanca and Tissue Service of the San Francisco Clinic (León, Spain) for the cells provided. This research was supported by funds from the Ministry of Science and Education (MEC) and Savings Bank Federation of Castilla y León. The authors gratefully acknowledge the financial support.

\section{REFERENCES}

[1] Jimenez MF, Varela G, Novoa N, et al. La lobectomía broncoplástica frente a la neumonectomía en el tratamiento del carcinoma de pulmón no microcítico. Arch Bronconeumol 2006; 42: 160-64.

[2] Cerfolio RJ. The incidence, etiology, and prevention of postresectional bronchopleural fistula. Semin Thorac Cardiovasc Surg 2001; 13: 3-7.

[3] Perets A, Baruch Y, Weisbuch F, et al. Enhancing the vascularization of three-dimensional porous alginate scaffolds by incorporating controlled release basic fibroblast growth factor microspheres. J Biomed Mater Res A 2003; 65: 489-97.

[4] Gerber HP, Vu TH, Ryan, AM, et al. VEGF couples hypertrophic cartilage remodeling, ossification and angiogenesis during endochondral bone formation. Nat Med 1999; 5: 623-28. 
[5] Shaulian E. Induction of Mdm2 and enhancement of cell survival by bFGF. Oncogene 1997; 15(22): 2717-25.

[6] Montrucchio G. Tumor necrosis factor $\alpha$-induced angiogenesis depends on in situ platelet-activating factor biosynthesis. J Exp Med 1994; 180: 377-82.

[7] Bennett S, Breit SN. Variables in the isolation and culture of human monocytes that are of particular relevance to studies of HIV. J Leukoc Biol 1994; 56: 236-40.

[8] Kobayashi K, Suzuki T, Nomoto Y, et al. Potential of heterotopic fibroblasts as autologous transplanted cells for tracheal epithelial regeneration. Tissue Eng 2007; 13: 2175-84.

[9] Goto Y, Noguchi Y, Nomura A, et al. In vitro reconstitution of the tracheal epithelium. Am J Respir Cell Mol Biol 1999; 20: 312-18.

[10] Yancopoulos GD, Davis S, Gale NW, et al. Vascular-specific growth factors and blood vessel formation. Nature 2000; 407: 24248.

[11] Benita S. Microencapsulation methods and industrial applications. Marcel Dekker: New York, 1996.

[12] Orive G, Hernandez RM, Gascon AR, et al. Cell encapsulation: promise and progress. Nat Med 2003; 9: 104-7.

[13] Angelova N, Hunkeler D. Rationalizing the design of polymeric biomaterials. Trends Biotechnol 1999; 17: 409-21.

[14] Orive G, Hernandez RM, Gascon AR, et al. History, challenges and promises of cell microencapsulation. Trends Biotechnol 2004; 22: 87-92.

[15] De Vos P, Hamel AF, Tatarkiewicz K. Considerations for successful transplantation of encapsulated pancreatic islets. Diabetología 2002; 45: 159-73.
[16] Herrero EP, Del Valle EMM, Galan MA. Immobilisation of Mesenchymal stem cells and monocytes in biocompatible microcapsules to cell therapy. Biotechnol Prog 2007; 23: 940-45.

[17] Jain K, Yang H, Cai B-R, et al. Retrievable, replaceable, macroencapsulated pancreatic islet xenografts. Long-term engraftment without immunosuppression. Transplantation 1995; 59: 319-24.

[18] Kizilel S, Garfinkel M, Opara E. The bioartificial pancreas: progress and challenges. Diabetes Technol Ther 2005; 7(6): 968-85.

[19] Alperin C, Zandstra PW, Woodhouse KA. Polyurethane films seeded with embryonic stem cell-derived cardiomyocytes for use in cardiac tissue engineering applications. Biomaterials 2005; 26 : 7377-86.

[20] Del Pozo A, Del Valle EMM, Galan MA. Kinetical diffusion studies of alginate-calcium and alginate barium microcapsules and determination of influence of factors implied in their production using doe. J Membr Sci 2007; (Submitted).

[21] Hermes RS, Narayani R. Polymeric alginate films and alginate beads for the controlled delivery of macromolecules. Trends Biomater Artif Organs 2002; 15: 54-6.

[22] Wan Chan L, Huey Ying L, Heng PWS. Mechanisms of external and internal gelation and their impact as a coat and delivery system. Carbohydr Polymer 2006; 63: 176-87.

[23] Mosmann T. Rapid colorimetric assay for cellular growth and survival: application to proliferation and cytotoxicity assays. J Immunol Methods 1983; 65: 55-63.

[24] Uludag H, Sefton MV. Microencapsulated human hepatoma (Hepg2) cells-in vitro growth and protein release. J Biomed Mater Res 1993; 27: 1213-24.

(C) Del Valle et al.; Licensee Bentham Open.

This is an open access article licensed under the terms of the Creative Commons Attribution Non-Commercial License (http://creativecommons.org/licenses/ by-nc/3.0/) which permits unrestricted, non-commercial use, distribution and reproduction in any medium, provided the work is properly cited. 